\title{
ROLE OF RURAL WOMEN IN DECISION MAKING REGARDING LIVESTOCK MANAGEMENT ACTIVITIES: A CASE STUDY IN EL- ABADIA VILLAGE, DAMANHOUR DISTRICT, EL- BEHIRA GOVERNORATE, EGYPT. Jacinthe Ibrahim Rihan
}

Rural Sociology and Agriculture Extension Department, Faculty of Agriculture, Ain Shams University, Arab Republic of Egypt.

\begin{abstract}
Livestock in generally considered one of the actors of the agricultural production. Rural women play an important roles in livestock production and marketing in the rural economies of developing countries as unpaid workers. They embark on various activities of livestock management like feeding, cleaning, collecting manure for organic fertilizer and milking. However, their involvement as decision makers regarding various livestock activities is still dubious. Hence the present study was carried out, with main objectives to investigate the involvement of rural women in the management of livestock activities, and to examine the role of rural women in taking decisions related to livestock activities. A systematic random sample of 150 female wives respondents were selected from ELAbadia village, Damanhour district, El- Behira Governorate. Data were collected using interview guided by pre-tested interview questionnaire, and focus group discussions (FGDs) during November and December 2016. Data was analyzed using Statistical Package of Social Science (SPSS). The results revealed that rural women's involvement in livestock decision making activities was relatively high in activities like selling/ purchasing of egg, milk products, and selling/ purchasing of poultry. However, their involvement was relatively low in activities like cultivation of fodder for livestock, and number of livestock to be kept. Age, education status, years of women's livestock breeding experience, and household annual income, were the main socioeconomic factors which had affected the involvement of rural women in decision making process.
\end{abstract}

Key words: Decision making, Rural women, Livestock.

INTRODUCTION:

Agriculture is a major component of the Egyptian economy, contributing up to $14.5 \%$ of GDP and $28 \%$ of all jobs (USAID, 2017). Agriculture employs almost 45 percent of all women in the workforce (USAID, 2017).

Livestock production form an important component of the agricultural sector, representing about $24.5 \%$ of the agricultural gross domestic product with value of around 33.6 billion Egyptian Pounds in 2007 (SADS, 2009).

Fayoum J. Agric. Res. \& Dev., Vol. 32, No.1, January, 2018 
Livestock remain a lifeline for many of the world's poorest people. Cattle, goats, sheep, chickens and other farm animals form a portion of the livelihood portfolios of an estimated two- thirds of poor livestock keepers, totaling approximately 400 million people, are women (Thomton et al, 2002). Livestock sector is generally considered a key asset for rural livelihoods. It offers advantages over other agricultural sectors and is an entry point for promoting gender balance in rural areas.

Animal husbandry is an important part of Egyptian farming systems, it diversifies production and reduces the risk of economic loses through crop production. If well integrated into the household economy, it allows more efficient use of family labor and a secure cash income spread over the entire year. Livestock supply households with many important products for consumption and / or sale, the supply draught power and manure and also provide protein and other dietary supplements for children. In addition, livestock have important functions in the social life of many Egyptian communities, serving as indicators of wealth and status and other forms of social exchange.

According to sustainable agricultural development strategy (2030) (SADS, 2009)the Egyptian cattle population reached 4.6 million head, while the buffalo population reached 3.9 million head in 2006. Regarding small ruminants, the sheep population reached 5.4 million head, while the goat population accounted 3.9 million head in 2006.The Egyptian livestock sector depends mainly on the private sector, with majority of animal breeders being smallholder farmers and the share of the government sector is less than $2 \%$ of the total animal numbers (SADS, 2009).

The main characteristics of the Egyptian animal production sector are (SADS, 2009): a) $17.3 \%$ of the cattle population and $6 \%$ of the buffalo population are owned by people who do not own agricultural land; b) $89 \%$ of the cattle population and about $75 \%$ of the buffalo population are in agricultural holdings of less than 2.1 ha; c) $25 \%$ of the sheep and goat populations are owned by people who do not own agricultural land; d) $83 \%$ of the sheep population and about $87 \%$ of the goat population are in agricultural holdings of less than 2.1 ha.

In most developing countries, livestock production is largely in the hands of women (FAO, 2012). Egyptian rural women have been observed to be heavily engaged in almost all activities regarding livestock production with a very few exceptions. The role of women involves a wide range of tasks such as feeding animals, collecting fodder, cleaning animals and their sheds, making dung cakes for use as fuel, collecting manure for organic fertilizer, milking, milk processing and even marketing of animal products such as ghee and cheese. Women also look after poultry farming at the household level. The intensive involvement of women livestock management activities is productive in terms of saving money that would otherwise be spent in hiring

Fayoum J. Agric. Res. \& Dev., Vol. 32, No.1, January, 2018 
ROLE OF RURAL WOMEN IN DECISION MAKING REGARDING.... 3 Labor. Milk and milk products not only meet the household consumption needs but also help in income generation when the same are sold in the market for Cash. Livestock rearing substantially increase the work load of women who not only have to shoulder the daily burden of housework but to provide meal for all those working in the field as well. Egyptian society is a traditional male dominated society in which male has power, control over resources and has a higher status and position than female.

Women's decision making process was clearly related to the context in which they live, as urban women had more roles in decision making at household level but the rural women were not having an active role in decision making.

\section{Research Problem:}

Despite considerable involvement and contribution of rural women in various tasks related to livestock management activities, gender inequalities exist in controlling the process of decision making, particularly over the disposal of animals and animal products (Taneja, 2013).

\section{Justification of the Research:}

1- Given the increase of women's contribution of labor to livestock, questions regarding the nature of women's control over decisions regarding livestock management and marketing become important research issues since such control will affect not only production outcome and food security but also the social organization and social dynamics of many rural households.

2- Very few studies on livestock decision making activities at the household level has been conducted in Egypt. Consequently, it is extremely difficult to make conclusive statements regarding who makes decisions related to livestock production and marketing activities.

\section{Research Objectives:}

The objectives of this research can be summarized as follows:

1- Identify the rural women respondents according to some selected socioeconomic characteristics.

2- Determine the present level of rural women involvement related to livestock management activities.

3- Identify the extent of rural women involvement in decision making process regarding various livestock management activities.

4- Classify women respondent, according to the degree of their believing in male superiority, in making important decisions related to livestock management activities.

5- Determine the socio- economic factors affecting women's involvement in decision making process in livestock management activities.

\section{Literature Review:}

The following literature has been reviewed in this paper to study the role of rural women decision making process, regarding livestock management activities.

Fayoum J. Agric. Res. \& Dev., Vol. 32, No.1, January, 2018 
The IFAD (IFAD,2017) publication on women as livestock managers in developing countries points out that women are called upon to perform men's livestock responsibilities much more often than the reverse, with a corresponding increase in their workloads. Women usually share responsibility with men and children for the care of animals, and particular types of activity are more associated with women than men. For example women often have a prominent role in managing poultry (FAO, 1998; Tung, 2005) and dairy production (Tangka et al, 2000) and in caring for other animals that are housed and fed within the homestead. When tasks are divided, men are more likely to be involved in constructing animals sheds, grazing animals, marketing of large animals, and in marketing of products if women's mobility is constrained.

The influence of women is strong in the use of eggs, milk and poultry meat for home consumption and they often have control over marketing and the income from these products, perhaps for this reason poultry and small scale dairy projects have been popular investments for development projects aiming to improve the livelihood of rural women (Brovo, 2000).

In rural Pakistan the women's share in livestock decision making is quite significant (www.dawn.com). The decision on keeping the number of small animals is 98 per cent; large animals 82 per cent; and poultry birds 95 per cent. For selling poultry products and milk/ghee, 89 - 99 per cent (www.dawn.com).

Decision making is a daily activity that households and their members undertake in different areas of their individual and collective lives. It is an ever continuous process of social relations where decisions are made among various alternative choices, and power is exercised when there is more than one individual who is directly or indirectly affected by the respective decision making outcomes (BMZ, 2013). Power between married couples is defined as the potential ability of one partner to influence the behavior of other in the decision making arena of family life. This ability to influence allows a partner with power to pursue his / her own desire against the will of the other, even when disagreement is explicit (BMZ, 2013).

The family power process refers to the interaction techniques (such as discussion, persuasion, assertiveness, negotiation, coercion.) that are used by actors to pursue their goals. Finally, the family power outcome refers to who ultimately wins or makes the final decision. This framework may provide some insight into how individual control over socio- economic resources may determine intra- household decision making outcomes. Yet, it overlooks the ideological factors which may serve as a power base for individuals to influence intra- household decision making outcomes. Households do not make resource allocation decision in a vacuum, but in a wider institutional environment (such as the socio- cultural environment) which shapes decision making outcomes. In many traditional societies, social norms play a significant role in structuring power relations (Katz, 1991). Social norms,

Fayoum J. Agric. Res. \& Dev., Vol. 32, No.1, January, 2018 
ROLE OF RURAL WOMEN IN DECISION MAKING REGARDING.... 5 values and practices may perpetuate asymmetric power relations through preventing conflicts and making individuals accept the existing social order as given and beneficial to all (Kabeer, 2001).

Despite the importance of women involvement in family decision making, in most developing countries, women decision making power is limited to some extent. Husbands and wives both usually have a say over the use of resources, although there may be "unequal, often conflicting claims on resources for the satisfaction of basic needs" (Tangka, 2000).

While a women may have considerable power on some dimension of livestock management, e.g., on decisions regarding small stock such as sheep, goats, poultry and other animals especially in backyard systems, she may have at the same time very little power to take decisions regarding large stock such as cattle and buffalo (FAO, 2012). Such situations suggest that the study of women's power to take decision concerning livestock management requires one to identify the different spheres of power and to analyze them separately.

The level of women involvement in decision making process regarding livestock management depends on several factors such as: women's age, women's education, male dominance, resistance from family members, the resources that each member contributes (control over resources), traditional belief, cultural norms, and the degree of awareness about social rights (FAO, 2003; Habib, 2000).

Concerning the socio-economic factors affecting decision making power of women, several studies (Enete el al, 2010; and Jyoti et al, 1999) showed that household decision making was associated with: age of the women, level of women's education, the status of women at the household level (head of the household), size of land holding, years of women's farming experience, and household annual income.

\section{Methodology:}

\section{a) Population and sample:}

Research was conducted in El- Abadia village, Damanhour district, Behira governorate. It is a big traditional village in which the population is estimated by 94944 inhabitants (Behira Information Center, 2016). The size of land holding total agricultural land in the village is estimated by 3218 feddans. In which $70 \%$ of the population work in agriculture. The common cultivated crops are wheat, barley, bean, clover, rice, corn and tomato.

The size of animal wealth is estimated by 40000 heads of big stock (cows\& buffaloes).Number of breeders are estimated by 2500 . The common animal breeding in the village include cows, buffaloes, sheep, goats, and poultry. In addition to the widespread of diary and cheese production in the village. Women play a critical role both in farming and livestock production including marketing in terms of labor contribution and involvement in decision making process. In the village livestock is generally considered a key asset for rural livelihoods.

Fayoum J. Agric. Res. \& Dev., Vol. 32, No.1, January, 2018 
It offers advantages over other agricultural sectors because: a) most household members have access to livestock and are involved in production; b) livestock activity is considered a daily occupation animal products such as eggs and milk are produced, processed and marketed throughout the year, without seasonal restrictions. Women take responsibility for the majority of the work; c) livestock production systems offer the potential for introducing a wide range of small project activities such as milk processing.....etc.

A systematic random sample of 150 rural households from the mother village have been selected (Behira Information Center, 2016). Each household had at least one large stock (cow or buffalo). The housewives of these households, were the respondents of this study. Data was collected through direct interviews guided by pre- tested questionnaire during November and December 2016. Two focus group discussions (FDGs) were executed with men and women group to determine the list of livestock management activities which were included in the questionnaire (covering 14 activities), and to supplement on the information generated using the questionnaire.

After completion of the field survey, the data obtained from the respondents were edited, coded, compiled, tabulated and analyzed according to the objectives of the study.

Basic statistics parameters such as mean, standard deviation and rank were used in describing the research variables. Linear regression was used to analyze and determine the socio- economic factors affecting women involvement in decision making power in livestock management activities.

\section{b) Tools and Techniques:}

\section{1- Measurement of involvement index:}

To identify the involvement level in livestock management activities, the involvement index was used (Sailaja and Reddy, 2003; and Rihan, 2017).

The involvement index included three levels "Mostly ", "Occasionally" and "Not at all" or never done by women, which was assigned scores of 2, 1 and 0 respectively. For the purpose of ranking of different activities performed by women, the frequency of responses from each of the three levels of a specific activity was tabulated and multiplied by concerned score. Then they were added together to get the total score for each specific activity for the purpose of their ranking.

\section{2-Measurement of decision making index (DMI) (Dependent variable):}

In order to analyze and quantify women's decision making involvement in various livestock management activities, A decision making index (DMI) was used. The index covers different types of activities on which women were asked to indicate the extent of their involvement in decision making.

Women with no involvement (NI) in the decision making were given zero. Score of one was given if women were only informed (OI) about decision, or consulted and her opinion was given no weight. A score of two scores was given if women's opinion was given some weight (OC) and involved in

Fayoum J. Agric. Res. \& Dev., Vol. 32, No.1, January, 2018 
ROLE OF RURAL WOMEN IN DECISION MAKING REGARDING.... 7 decision making process. Finally, a score of three was given if the women took decisions independently (ID). The decision making score obtained by a women was calculated by the following formula:

$\mathrm{NI} \times 0+\mathrm{OI} \times 1+\mathrm{OC} \times 2+\mathrm{ID} \times 3$

The decision making index (DMI) is computed as follows:

Decision making score obtained by a women/ maximum possible score of respondent women $\times 100$. The higher the index score, the greater the indication of gender equity in decision making. Aggregated individual index score provide a measure of gender equity within the region.

\section{3-Measurement of independent variables:}

According to the review of literature mentioned above, six socioeconomic factors affecting decision making power of women were selected for analysis, namely:

Age of women, educational status, female headed households, number of livestock maintained (size of livestock holding by head of animals), years of women's livestock breeding experience, and household annual income. The measurement of the six independent variables are as follows:

- Age of the women respondent is measured in terms of actual years on the basis of her statement.

- Education is measured by the number of years of schooling.

- Female headed household identified as the adult female (wife), sole or main income generator and decision maker. These household usually are headed by widows or divorced women. The scores given are 1 to the households headed by women, and 0 otherwise.

- Size of livestock holding, referred to the number of big stocks (cows \& buffaloes) raised by the household members, accounted by head.

- Years of women's livestock breeding experience, referred to the number of years that women respondents spent in breeding livestock.

- Household annual income of the respondents is measured in Egyptian pounds on the basis of total earning from agricultural and non- agricultural sources of the family per year.

\section{c) Hypothesis:}

To test the fifth objective of the study, concerning the socio- economic factors affecting women's involvement in decision making process in livestock management activities, six hypothesis were framed:

H0: there is no significant relationship between socio- economic characteristics (age, education, female headed households, size of livestock holding by head of animals, years of women's livestock breeding experience, and household annual income) of the women respondents and their level of involvement in livestock decision making power.

H1: there is significant relationship between socio- economic characteristics (age, education, female headed households, size of livestock holding by head of animals, years of women's livestock breeding experience, and household

Fayoum J. Agric. Res. \& Dev., Vol. 32, No.1, January, 2018 
annual income) of the women respondents and their level of involvement in livestock decision making power.

Independent Variables

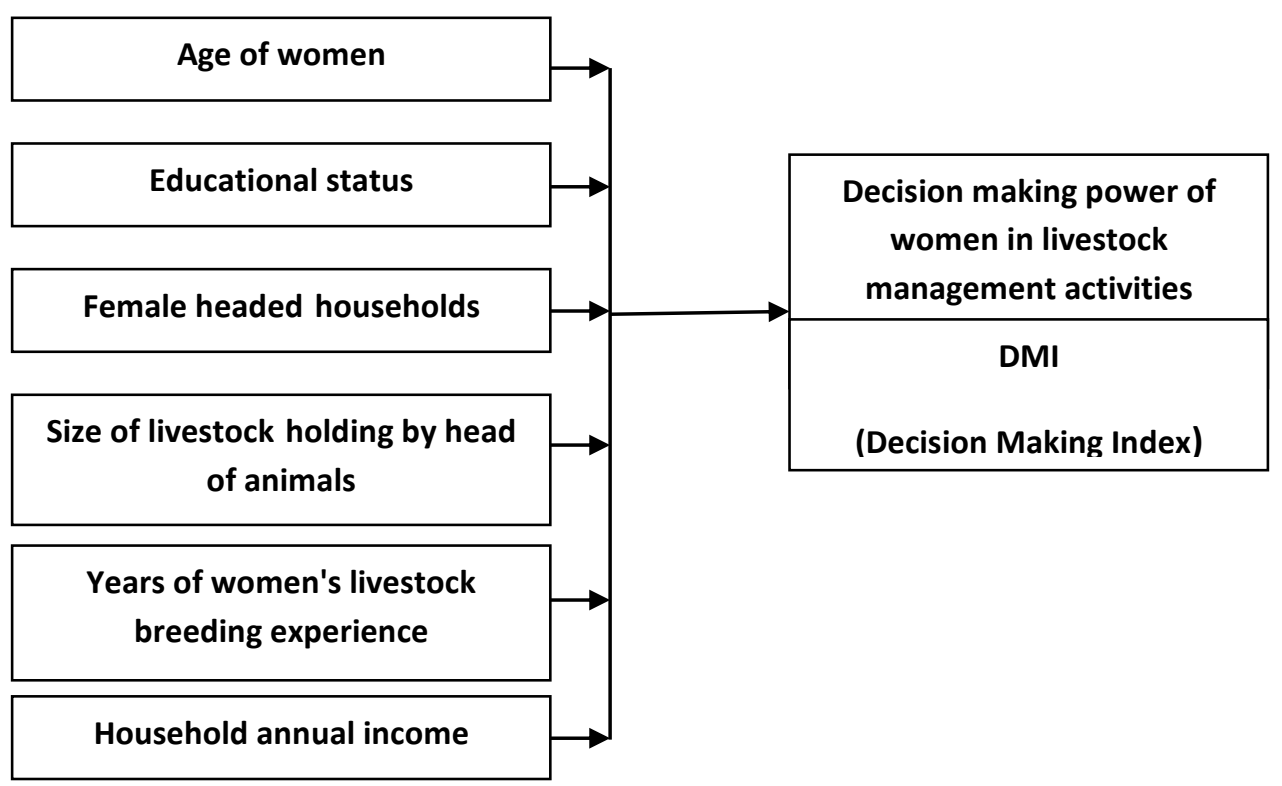

Figure 1: Conceptual Framework

\section{Results and Discussion:}

\section{1- Socio- economic characteristics of the respondents:}

Data regarding socio-economic characteristics of respondents in table (1) shows that $(48.7 \%)$ of the respondents belonged to older age group (51 years and above) followed by (32.0\%) and (19.3\%) to the younger (up to 35 years) and middle (36- 50 years) aged groups respectively. In case of education level about (36.7\%) of the respondents had no formal education degree (illiterate), while the remaining $(63.3 \%)$ were literate/ educated. Among the literate, respondents $(27.3 \%)$ only attended primary school, $(24.7 \%)$ attended till middle schooling, while only $(11.3 \%)$ attended to higher institutions. In case of marital status, the large majority $(95.3 \%)$ of the respondents were married compared with $(2.7 \%)$ were widowed, and only (2.0\%) of the respondents were divorced.

The total number of big stock mainly buffaloes and cows 335 heads owned by 150 respondents (total sample); which are classified into three categories as follows: first category ( 82 heads) represents $(24.5 \%)$ of total heads owned by $(52 \%)$ of total household, second category (198 heads) represents $(59.1 \%)$ of total heads owned by $(41.3 \%)$ of households, and third category (55 heads) represents $(16.4 \%)$ of total heads owned by $(6.7 \%)$ of households.

The total number of small stock mainly sheep and goats 367 heads owned by 150 respondents (total sample); which are classified into three categories as

Fayoum J. Agric. Res. \& Dev., Vol. 32, No.1, January, 2018 
ROLE OF RURAL WOMEN IN DECISION MAKING REGARDING.... 9 follows: first category ( 89 heads) represents $(24.2 \%)$ of total heads owned by $(51.3 \%)$ of households, second category (188 heads) represents $(51.2 \%)$ of total heads owned by (37.3\%) of households, and the third category (90 heads) represents $(24.6 \%)$ of total heads owned by $(11.3 \%)$ households.

The average number of years of livestock breeding experience of the women respondents was 29 years. (10\%) of them had less than 10 years of livestock breeding experience; (16\%) had between 11- 20 years of experience, while (74\%) of them had above 21 years' experience. This implies that the majority of the women respondents had a high number of years of livestock breeding experience.

The household annual income (calculated in thousand LE) was divided into 3 categories as follows; the first category (less than 25,000 LE) represents (28.7\%) of households, while the second category vary from (25.000 to 60.000 LE) represents the majority by $(68.7 \%)$ of households, while the third category is (60.000 LE and above) represents (2.6\%) of households.

Table (1): Distribution of the women respondents according to some selected socio- economic characteristics.

\begin{tabular}{|c|c|c|c|}
\hline \multirow{2}{*}{ Characteristics } & \multirow{2}{*}{ Categories } & \multicolumn{2}{|c|}{ Respondents } \\
\hline & & No. & $\%$ \\
\hline 1- Age & $\begin{array}{l}\text { Young ( up to } 35 \text { years) } \\
\text { Middle ( } 36-50 \text { years) } \\
\text { Old ( } 51 \text { and above) }\end{array}$ & $\begin{array}{l}48 \\
29 \\
73\end{array}$ & $\begin{array}{l}32.0 \\
19.3 \\
48.7\end{array}$ \\
\hline 2- Education & $\begin{array}{c}\text { Illiterate }(0) \\
\text { Primary schooling (1- } 6 \text { years) } \\
\text { Mid schooling ( } 7-12 \text { years }) \\
\text { University (13- } 18 \text { years) }\end{array}$ & $\begin{array}{l}55 \\
41 \\
37 \\
17\end{array}$ & $\begin{array}{l}36.7 \\
27.3 \\
24.7 \\
11.3\end{array}$ \\
\hline 3- Marital status & $\begin{array}{c}\text { Married } \\
\text { Widowed (women headed household) } \\
\text { Divorced (women headed household) }\end{array}$ & $\begin{array}{c}143 \\
4 \\
3\end{array}$ & $\begin{array}{l}95.3 \\
2.7 \\
2.0\end{array}$ \\
\hline 4- Size of livestock holding by head & & & \\
\hline a- Buffaloes \& Cows & $\begin{array}{c}\text { 1- } 2 \text { heads (total No.82, 24.5\%) } \\
\text { 3-4 heads (total No.198, 59.1\%) } \\
5+\text { heads (total No. 55, 16.4\%) }\end{array}$ & $\begin{array}{l}78 \\
62 \\
10\end{array}$ & $\begin{array}{c}52.0 \\
41.3 \\
6.7\end{array}$ \\
\hline b- Sheep \& Goats & $\begin{array}{c}\text { 1- } 2 \text { heads (total No.89, 24.2\%) } \\
\text { 3-4 heads (total No.188, 51.2\%) } \\
5 \text { +heads (total No.90, 24.6\%) }\end{array}$ & $\begin{array}{l}77 \\
56 \\
17\end{array}$ & $\begin{array}{l}51.3 \\
37.3 \\
11.3\end{array}$ \\
\hline $\begin{array}{l}\text { 5- Years of livestock breeding } \\
\text { experience }\end{array}$ & $\begin{array}{c}\text { Less than } 10 \text { years } \\
11-20 \text { years } \\
\text { Above } 20 \text { years } \\
\end{array}$ & $\begin{array}{c}15 \\
24 \\
111 \\
\end{array}$ & $\begin{array}{l}10.0 \\
16.0 \\
74.0 \\
\end{array}$ \\
\hline 6- Household annual income (000LE) & $\begin{array}{l}\text { Less than } 25 \\
\text { 25- } 60 \\
\text { More than } 60\end{array}$ & $\begin{array}{c}43 \\
103 \\
4\end{array}$ & $\begin{array}{c}28.7 \\
68.7 \\
2.6\end{array}$ \\
\hline
\end{tabular}

Generally, the main socioeconomic characteristics of the respondents can be summarized in the following: old in age above 51years, low level of education as more than one third of the respondents were illiterate, more than half of the respondents are between primary and middle schooling, married, hold limited

Fayoum J. Agric. Res. \& Dev., Vol. 32, No.1, January, 2018 
number of livestock but with long experience in livestock breeding which make them very skilled in which more than half of households respondents gain an average of 25.000-60.000LE annually.

\section{2- Level of involvement of rural women, relating to livestock management} activities:

Distribution of the rural women respondents according to the extent of involvement in various livestock management activities along with involvement indices and rank order is depicted in table (2). Table (2) reveals that the overwhelming majority of the respondents involved "mostly" in cleaning of animal sheds ( $82.7 \%)$, followed by feeding and caring of livestock/ poultry $(77.3 \%)$, milking of animals $(76.7 \%)$, egg collection of poultry birds (76.0\%), preparing ghee/ milk products $(74.7 \%)$, selling of milk and milk products, selling of egg each reported by $(73.3 \%)$.

Women "occasionally" involved in "making and storing of dung cakes", selling of milk, milk products, and poultry (hen\& cock) as responded by $(23.3 \%),(22.7 \%)$, and $(22.0 \%)$ of the respondents respectively. But on the other side women " not at all " involved in selling/ purchasing of livestock (cows \& buffaloes), and selling/ purchasing of small ruminant (sheep\& goat) as reported by (97.3\%) and (89.3\%) of the respondents respectively.

It is acknowledged that among all the livestock production and management activities, rural women perform most of them. Cleaning of animal shed, egg collection of poultry birds, feeding and caring of livestock/ poultry, selling of milk and milk products and milking of animals are the main livestock activities with better rank orders which were being performed by rural women. 
ROLE OF RURAL WOMEN IN DECISION MAKING REGARDING.... 11 Table (2): Distribution of the women respondents according to the extent of their involvement in livestock management activities.

\begin{tabular}{|c|c|c|c|c|c|c|c|c|}
\hline \multirow{3}{*}{ Livestock activities } & \multicolumn{8}{|c|}{ Extent of involvement } \\
\hline & \multicolumn{2}{|c|}{ Mostly } & \multicolumn{2}{|c|}{ Occasionally } & \multicolumn{2}{|c|}{ Not at all } & \multirow{2}{*}{$\begin{array}{l}\text { Involvement } \\
\text { indices }\end{array}$} & \multirow{2}{*}{$\begin{array}{l}\text { Rank } \\
\text { order }\end{array}$} \\
\hline & No. & $\%$ & No. & $\%$ & No. & $\%$ & & \\
\hline \multicolumn{9}{|l|}{ a- Production activities } \\
\hline $\begin{array}{l}\text { 1- Cleaning of animals } \\
\text { sheds }\end{array}$ & 124 & 82.7 & 21 & 14.0 & 5 & 3.3 & 269 & 1 \\
\hline $\begin{array}{l}\text { 2- Feeding and caring of } \\
\text { livestock/ poultry }\end{array}$ & 116 & 77.3 & 23 & 15.3 & 11 & 7.4 & 255 & 3 \\
\hline $\begin{array}{l}\text { 3- Watering of animals } \\
\text { and poultry birds }\end{array}$ & 20 & 13.3 & 21 & 14.0 & 109 & 72.7 & 61 & 10 \\
\hline 4- Milking of animals & 115 & 76.7 & 23 & 15.3 & 12 & 8.0 & 253 & 5 \\
\hline $\begin{array}{l}\text { 5- Preparing ghee/ milk } \\
\text { products }\end{array}$ & 112 & 74.7 & 20 & 13.3 & 18 & 12.0 & 244 & 7 \\
\hline $\begin{array}{c}\text { 6- Egg collection of poultry } \\
\text { birds }\end{array}$ & 114 & 76.0 & 28 & 18.7 & 8 & 5.3 & 256 & 2 \\
\hline 7- Grazing of animals & 8 & 5.3 & 20 & 13.3 & 122 & 81.3 & 36 & 11 \\
\hline \begin{tabular}{|c|}
$\begin{array}{c}\text { 8- Making and storage of } \\
\text { dung cakes }\end{array}$ \\
\end{tabular} & 91 & 60.7 & 35 & 23.3 & 24 & 16.0 & 217 & 9 \\
\hline 9- Animal health treatment & 3 & 2.0 & 27 & 18.0 & 120 & 80.0 & 33 & 12 \\
\hline \multicolumn{9}{|l|}{$\underline{\text { b- Marketing activities }}$} \\
\hline \begin{tabular}{|l|} 
10- Selling/ purchasing of \\
livestock (cow $\mid \&$ buffalo)
\end{tabular} & 2 & 1.3 & 2 & 1.3 & 146 & 97.3 & 6 & 14 \\
\hline $\begin{array}{c}\text { 11- Selling/ Purchasing of } \\
\text { small ruminant (sheep\& } \\
\text { goat) }\end{array}$ & 2 & 1.3 & 14 & 9.3 & 134 & 89.3 & 18 & 13 \\
\hline $\begin{array}{l}\text { 12- Selling of poultry* } \\
\text { (hen/ cock) }\end{array}$ & 105 & 70.0 & 33 & 22.0 & 12 & 8.0 & 243 & 8 \\
\hline 13- Selling of egg (poultry) & 110 & 73.3 & 32 & 21.3 & 8 & 5.3 & 252 & 6 \\
\hline $\begin{array}{l}\text { 14- Selling of milk and } \\
\text { milk products }\end{array}$ & 110 & 73.3 & 34 & 22.7 & 6 & 4.0 & 254 & 4 \\
\hline
\end{tabular}

* Includes: chicken, turkeys, ducks and geese

3- Rural women involvement in decision making process regarding various livestock management activities:

The decision making index (DMI) score was grouped as low (0-40), medium (40-70) and high (70-100) based on range of (DMI) score. The results are presented in table (3). It is observed from the table that 68.0 percent of women respondents fall in the medium category in decision making index (DMI score 41 to 70). Only $18 \%$ of women respondents were in the high category of DMI (DMI score 71- 100).

Fayoum J. Agric. Res. \& Dev., Vol. 32, No.1, January, 2018 
Table (3): Distribution of women respondents by Decision making Index (DMI).

\begin{tabular}{|c|c|c|}
\hline \multirow{2}{*}{ DMI score categories } & \multicolumn{2}{|c|}{ Respondents } \\
\cline { 2 - 3 } & No. & \% \\
\hline Low $(0-40)$ & 21 & 68.0 \\
\hline Medium $(40-70)$ & 102 & 14.0 \\
\hline High $(70-100)$ & 27 & 18.0 \\
\hline
\end{tabular}

The extent of involvement of rural women in decision making in various livestock activities has been shown in table (4). This was determined on the basis of degree of involvement (consultation) of husbands with their spouse in respect of various livestock activities listed in table (4).

The overall results indicating the degree of involvement between the respondents and their husbands in various livestock activities, have been classified under three categories (No involvement, Joint decision, and fully involved in final decision) according to the frequency distribution of the opinion of the respondents.

The values indicating the range of "no involvement" between the respondents and their spouses regarding livestock activities varied from 1.3 to $34 \%$ (table 4).

Under the category of "joint decision" consolation between the respondents and their spouses, the range varied from $16 \%$ to $39.3 \%$ for only consulted, and from $24.7 \%$ to $42 \%$ from "opinion considered".

Table (4): Extent of rural women involvement in decisions related to livestock management activities.

\begin{tabular}{|c|c|c|c|c|c|c|c|c|c|c|}
\hline \multirow{4}{*}{ Decisions areas } & \multicolumn{8}{|c|}{ Extent of involvement in decision making } & \multirow{4}{*}{$\begin{array}{l}\text { Decision } \\
\text { scores }\end{array}$} & \multirow{4}{*}{$\begin{array}{l}\text { Rank } \\
\text { order }\end{array}$} \\
\hline & \multirow{2}{*}{\multicolumn{2}{|c|}{$\begin{array}{c}\text { (Nil) } \\
\text { No } \\
\text { involvement }\end{array}$}} & \multicolumn{4}{|c|}{ Joint decision } & \multirow{2}{*}{\multicolumn{2}{|c|}{$\begin{array}{c}\text { Independent decision } \\
\text { (Fully involved in } \\
\text { final decision) }\end{array}$}} & & \\
\hline & & & \multicolumn{2}{|c|}{$\begin{array}{c}\text { Only } \\
\text { consulted }\end{array}$} & \multicolumn{2}{|c|}{$\begin{array}{c}\text { Opinion } \\
\text { considered }\end{array}$} & & & & \\
\hline & No. & $\%$ & No. & $\%$ & No. & $\%$ & No. & $\%$ & & \\
\hline $\begin{array}{c}\text { 1- Number of livestock } \\
\text { to be kept }\end{array}$ & 51 & 34.0 & 43 & 28.7 & 49 & 32.7 & 7 & 4.7 & 162 & 7 \\
\hline $\begin{array}{c}\text { 2- Cultivation of fodder } \\
\text { for livestock }\end{array}$ & 50 & 33.3 & 48 & 32.0 & 45 & 30.0 & 7 & 4.7 & 159 & 8 \\
\hline $\begin{array}{l}\text { 3- Selling/ purchasing of } \\
\text { livestock (cow } \mid \& \text { buffalo) }\end{array}$ & 19 & 12.7 & 59 & 39.3 & 37 & 24.7 & 35 & 23.3 & 238 & 5 \\
\hline $\begin{array}{l}\text { 4- Selling/ Purchasing } \\
\text { of small ruminant } \\
\text { (sheep\& goat) }\end{array}$ & 14 & 9.3 & 55 & 36.7 & 42 & 28.0 & 39 & 26.0 & 256 & 4 \\
\hline $\begin{array}{l}\text { 5- Selling/purchasing of } \\
\text { poultry* (hen\& cock..) }\end{array}$ & 4 & 2.6 & 34 & 22.7 & 52 & 34.7 & 60 & 40.0 & 318 & 3 \\
\hline $\begin{array}{c}\text { 6- Selling / purchasing } \\
\text { of egg (poultry) }\end{array}$ & 4 & 2.6 & 24 & 16.0 & 50 & 33.3 & 72 & 48.0 & 340 & 1 \\
\hline $\begin{array}{l}\text { 7- Selling / purchasing of } \\
\text { milk and milk products }\end{array}$ & 2 & 1.3 & 32 & 21.3 & 42 & 28.0 & 74 & 49.3 & 338 & 2 \\
\hline $\begin{array}{c}\text { 8- Making artificial } \\
\text { insemination }\end{array}$ & 44 & 29.3 & 25 & 16.7 & 63 & 42.0 & 18 & 12.0 & 205 & 6 \\
\hline Mean & & .5 & 40 & & & & & & 2.52 & \\
\hline
\end{tabular}

* Poultry includes: chicken, turkeys, ducks and geese

Fayoum J. Agric. Res. \& Dev., Vol. 32, No.1, January, 2018 
ROLE OF RURAL WOMEN IN DECISION MAKING REGARDING.... 13

The values indicating the range of "independent decision" or fully involved in final decision, consultation between the respondents and their spouse in livestock making activities varied from $(4.7 \%)$ to $(49.3 \%)$.

It is clear from table (4) that husbands consider the opinion of their wives in decision making for activities of making artificial insemination, selling/ purchasing of poultry and selling/ purchasing of egg which actually reported by $(42.0 \%),(34.7 \%)$ and $(33.3 \%)$ of the respondents, respectively. In the study sample decisions about purchase and sale of cows and buffaloes traditionally were made by male family members, although (64\%) of women respondents were involved in joint decision, final say was of men. Regarding number of livestock to be kept, $(4.7 \%)$ of women respondents heading the family took independent decision, and (61.4\%) were involved in joint decision.

Concerning the role of rural women in final decision, the highest percentage of responses were found in the case of "selling/ purchasing of milk \& milk products" (49.3\%), followed by "Selling / purchasing of poultry egg" and "Selling / purchasing of poultry" each reported by (48\%) and (40\%) respectively. The least involvement of rural women in final decision were observed in "number of livestock to be kept", cultivation of fodder for livestock" and "making artificial insemination that reported by (4.7\%) for each of the first and second, and (12.0\%) for the third of the respondents, respectively.

Regarding cultivation of fodder for livestock only (4.7\%) of the respondents took independent decision and (62.0\%) were involved partially. Concerning selling/ purchasing of milk and milk products the major decision were made by women that reported $(49.3 \%)$ of the respondents were fully independent in their decisions.

4- Classification of women respondents, according to the degree of their believing in male superiority, in making important decisions related to livestock management activities:

Table (5): Distribution of women respondents according to their believing in male superiority, in making important decisions related to livestock management activities.

\begin{tabular}{|c|c|c|}
\hline Response & frequency & percentage \\
\hline To a great extent & 97 & 64.7 \\
\hline To some extent & 41 & 27.3 \\
\hline Not at all & 12 & 8.0 \\
\hline
\end{tabular}

More than half of the respondents $(64.7 \%)$ believed in dominate role of husbands in making important decisions concerning family livestock affairs, whereas $(27.3 \%)$ were of the view that the males should have a limited role (to some extent) in livestock activities. Nearly (8\%) respondents tended to

Fayoum J. Agric. Res. \& Dev., Vol. 32, No.1, January, 2018 
disallow any role to the males in livestock activities especially in poultry sector.

The main point of views expressed above clearly indicates that the spouses, in general, yet believe in accepting the dominance of husbands in livestock activities or in other words they do not have the courage, confidence or capability to do most of it all by themselves.

5- Socio-economic factors affecting women's involvement in decision making process in livestock management activities:

The results of the regression analysis are summarized in table (6). It confirms the previous findings. Thus, age, education, and years of women's livestock breeding experience are found to have a strong positive impact on DMI, while household annual income have a negative impact. Status of women in the household has an expected positive impact on DMI, but regression coefficient is not significant. Size of livestock holding also has a negative impact, but not statistically significant. The value of $\mathbf{R}$ square (coefficient of determination) is 0.31. It means that the identified six independent variables representing socio- economic characteristics of respondents women, explain only $31 \%$ of the variability of decision making power in livestock management activities. This indicates that the factors affecting women involvement in decision making power in livestock management activities are quite complex and depend upon a large number of socio- economic factors including traditional social and cultural values.

Table(6): Linear regression between socio- economic variables (Independent variables) and decision making power (DMI- dependent variable) of women respondents in livestock management activities.

\begin{tabular}{|c|c|c|c|}
\hline Independent variables & Coefficient & Std. Err. & T value \\
\hline Constant & 21.282791 & 6.015440 & 2.791 \\
\hline Age of women & 0.541788 & 0.080153 & $5.320^{*}$ \\
\hline Educational status & 0.005184 & 0.001391 & $5.721 * *$ \\
\hline Head of the household & 1.403353 & 1.181907 & 1.466 \\
\hline Size of livestock holding & -0.504233 & 0.371322 & -1.322 \\
\hline $\begin{array}{l}\text { Years of women's livestock breeding } \\
\text { experience }\end{array}$ & 0.005184 & 0.001381 & $5.732 * *$ \\
\hline Household annual income & -0.000014 & 0.000005 & -2.412 \\
\hline
\end{tabular}

The coefficients of the independent variables in the regression analysis (table 6) could be interpreted as follows:

- A one unit change in age of women is associated with a 0.541 unit change in the predicted value of the decision making power of women respondents in livestock management activities.

- A one unit change in education of women is associated with a 0.005 unit change in the predicted value of the decision making power of women respondents in livestock management activities.

Fayoum J. Agric. Res. \& Dev., Vol. 32, No.1, January, 2018 
ROLE OF RURAL WOMEN IN DECISION MAKING REGARDING.... 15

- A one unit change in "head of the household", "size of livestock holding", "years of women's livestock breeding experience", and " household annual income" are associated with 1.403, - 0.504, 0.005, and -0.00 unit change in the predicted value of the decision making power of women respondents in livestock management activities respectively.

\section{CONCLUSION:}

From the findings and discussion stated above, it could be mentioned that rural women are key players in the livestock sector of the study area. They undertake various activities of livestock management. They mostly engaged and participated in cleaning of animals sheds, feeding and caring of livestock/ poultry, milking of animals, egg collection of poultry birds, preparing ghee/ milk products and others.

However, the level of their involvement was limited in watering of animals, grazing of animals, selling/ purchasing of big stocks like cow\& buffalo, and small ruminant like sheep\& goats which traditionally consider only implemented by men.

Despite this major role, men have reportedly continued to dominate most of livestock decision making activities, even in areas where women are the largest providers of labor. Most rural women did not have any role in decision making with regard to " number of livestock to be kept " , " cultivation of fodder for livestock ", " making artificial insemination ", selling/ purchasing of big stocks (cow\& buffalo) and selling/ purchasing of small ruminant (sheep\& goat).Rural women's involvement in livestock decision making generally is quite minimal. This can be attributed to the age, education, years of women livestock breeding experience, and household annual income. About $37 \%$ of the women interviewed were however found not to be formally educated, and most of them belonged to low and middle household income.

A large majority of the respondents believed in dominant role of husbands in making important decisions concerning livestock affairs. The extent to which women have access to the benefits of livestock and the involvement in decision making depends on men's approval. Poverty stricken families often require the contribution of women to keep the family out from a state of utter poverty. As a result, women from poorer households tend to play a greater role in livestock production than women from relativity well off families.

Women may have no or very little power to take decisions due to many reasons like lack of education, lack of control over resources, low level of awareness of their civic/ human rights, and lake of credit facilities. In general, women have less access to the means of production in comparison to the extent of their labor contribution. The division of labor as dictated by tradition in the study sample is not always necessarily followed and women often

Fayoum J. Agric. Res. \& Dev., Vol. 32, No.1, January, 2018 
perform tasks reserved for men because of labor shortages, although men rarely perform tasks which are assigned to women.

Despite the importance women involvement in livestock decision making, in the study sample, women decision making power is limited to some extent. While a woman may have considerable power on some dimensions of livestock production and marketing, e.g., on decisions regarding micro livestock (small ruminant and poultry) as well as in dairy, including the processing and marketing of milk and milk products, women may have at the same time very little power to sell or purchase a cow or buffalo. Women likewise make important decisions when the household is female- headed, or when enterprise is one in which women predominate, such as poultry, milking and dairy products as mentioned above.

\section{Recommendations:}

Livestock provides animal protein in the form of milk, meat and eggs which is a base for industrial raw material like: wool, hides, skins, organic fertilizer for crops, security against crop failures, and financial support in difficult times of the farmers. In the way livestock is the driving force for rural development. Since livestock is mostly raised by women, their involvement is closely linked with economic empowerment and social wellbeing of women. The rapidly increasing demand for livestock products creates opportunities for empowerment of women. Women from rural areas need specific empowerment programs to enable them to be more autonomous in the household decision making in general, and in livestock management activities in particular. Women's autonomy by education, access to community resources, and challenge harmful traditional norms will lead the women to be more autonomous in decision making especially in economic areas where she is considered the key actor like livestock management activities.

Finally, ensuring women's access to and control of resources such as land, livestock, markets, information and credit strengthens their influence and social empowerment. Designing livestock development programs with a targeted gender approach will therefore improve the overall program impact in terms of poverty reduction and food security. Thus, attention should be given for rural women to build their capabilities in decision making.

\section{REFERENCES:}

Behira Information Center, (2016).

Enete A. A., Amusa T. A. (2010), "Determinants of women's contribution to farming decisions in cocoa based agroforestry households of Ekiti state, Nigeria ", field actions science report, www. Factsreports. Org (C) Authar (s) 2010.

FAO,(1998), village chicken production systems in rural Africa, household food security and gender issues, by A. J. Kitalyi, Rome.

Fayoum J. Agric. Res. \& Dev., Vol. 32, No.1, January, 2018 
ROLE OF RURAL WOMEN IN DECISION MAKING REGARDING.... 17

FAO, (2003), The uplift and empowerment of rural women in Pakistan, Rome (online).

FAO,(2012), Invisible guardians, women manage livestock diversity, FAO animal production and health.

BMZ, (2013), Federal ministry for economic cooperation and development,

(March 2013), Rural development, agriculture, food security, Berlin, Germany.

Habib N. (2002), Invisible farmers: a study on the role of women in agricultural and the impact of pesticides on them in Punjal, Khoj Res. And Public center, Lahore, Pakistan.

Ifad, (2017), www.Ifad.org.

Jyoti K. S., Sutyaprakesh C.P. (1999), " Empowerment and decision making by rural women ": An economic study kamatake, Indian Journal of Agricultural Economics, vol (53), No. 3, 308, 1999.

Kabeer N. (2001), conflicts over credit: Re- evaluating the empowerment potential of loans to women in Bangladish. World development, vol. 29 (1).

Katz E. (1991), Breaking the myth of harmony: theoretical and methodological guidelines to the study of rural third world households, review of radical political economics, vol. 23 (4).

Rihan, Jacinthe (2017), Rural women's involvement in agricultural and nonagricultural activities: A case study of Manshiet Damanhour village, El- Badrashen district, Giza governorate, Egypt, Fayoum J. Agric. Res. \& Dev. Vol. 31, No. 1, January, 2017, Egypt.

SADS (2009), Sustainable agricultural development strategy towards 2030, Agricultural Research \& Development Council, Ministry of Agriculture \& Land Reclamation, Egypt.

Sailaja A.; Reddy M.N. (2003), Changing needs of farm women in agriculture, MANAGE Extension Research Review, Rejendranagar, Hyderabad, India.

Taneja, V.K. (2013) women and livestock, http://www. Daily post in/ comments/ columnists/ 3034- women- and- livestock.

Tangka F.K.; Jabbar M.A.; and Shapiro B.I. (2000) Gender roles and child nutrition in livestock production systems in developing countries: A critical review socio- economics and policy research working paper 27. ILRI, Nairobi, Kenya.

Thomton P.K., Kruska R.L., Henninger N. Kristjanson P.M., Reid R.S., Atino F., Odero A.N. and Ndegwa T. (2002), Mapping poverty and livestock in the developing world, ILRI, Nairobi, Kenya.

Tung. D.X. (2005) Smallholder poultry production in Vietnam: Marketing characteristics and strategies, paper presented at the workshop "Does poultry reduce poverty? A need for rethinking the approaches, 30- 31 August, Copenhagen, Network for smallholder

Fayoum J. Agric. Res. \& Dev., Vol. 32, No.1, January, 2018 
poultry development.

USAID, (2017), www. Usaid.gov/ Egypt/agricultural-and- food- security. www. Dawn.com.

$$
\begin{aligned}
& \text { دور المرأة الريفية فى اتخاذ القرارات المتعلقة بادارة أنثطة الانتاج الحيوانى: دراسة حالة بقرية } \\
& \text { الأبعادية ، مركز دمنهور، محافظة البحيرة، مصر. } \\
& \text { جاسنت ابر اهيم ريحان إعنان } \\
& \text { قسم المجتمع الريفى و الارشاد الزر اعى،كلية الزراعة، جامعة عين شمس،جمهورية مصر العربية. }
\end{aligned}
$$

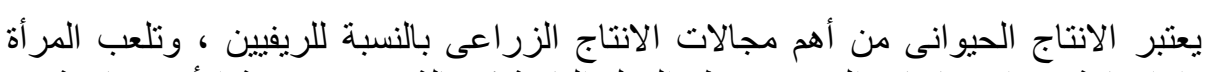

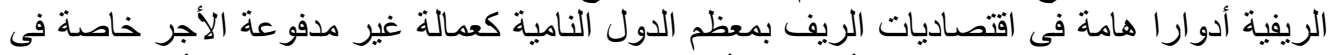

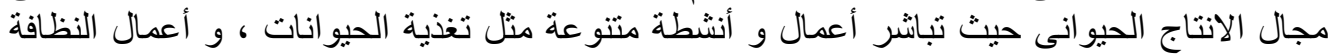

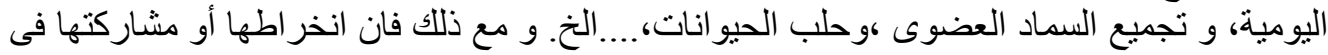

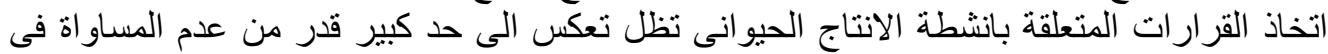

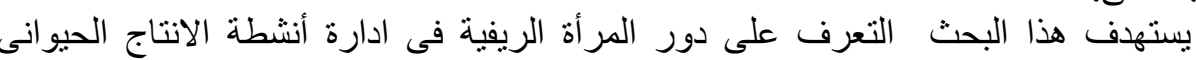

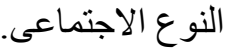

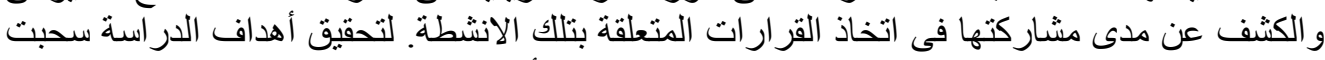

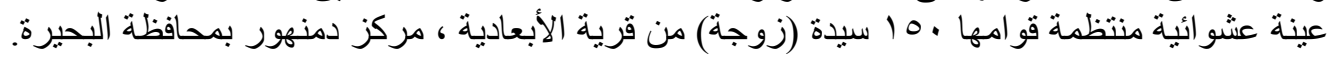

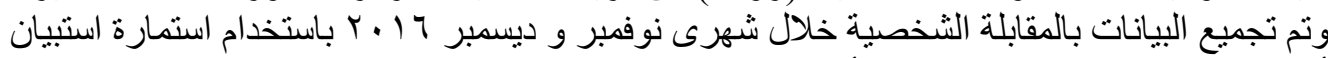

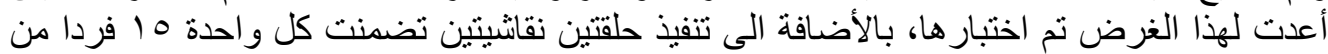

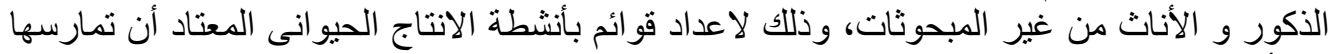

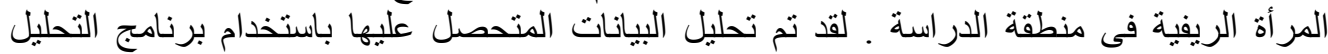

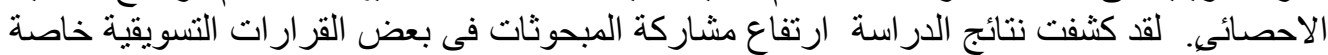

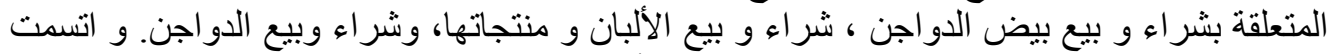

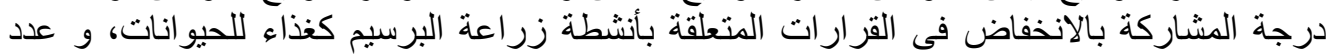

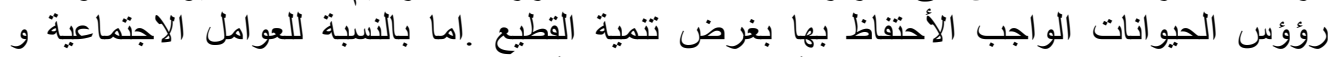

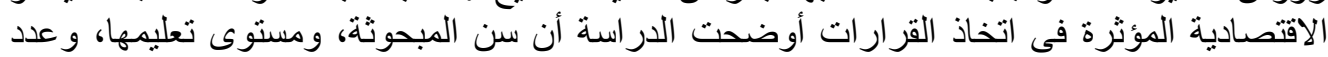

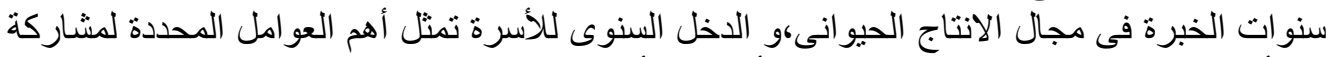

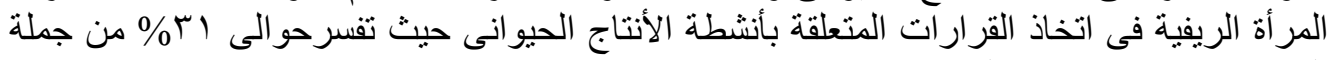
الكلمات الدالة: اتخاذ القرار اتثات، المر أة الريفية، الانتاج الحيو انى . 